\title{
Aflatoxin M1 in Fresh Dairy Milk from Small Individual Farms in Indonesia
}

\author{
Widiastuti R, Anastasia Y \\ Indonesian Research Center for Veterinary Science, Jl. RE Martadinata 30, Bogor 16114 \\ E-mail: widiastuti.raphaella@gmail.com
}

(received 18-02-2018; revised 25-06-2018; accepted 01-08-2018)

\begin{abstract}
ABSTRAK
Widiastuti R, Anastasia Y. 2018. Residu aflatoksin M1 pada susu sapi segar dari peternakan sapi rakyat di Indonesia. JITV 23(3): 143-149. DOI: http://dx.doi.org/10.14334/jitv.v23i3.1789

Penelitan ini bertujuan untuk mengetahui keberadaan residu aflatoksin M1 (AFM1) pada susu sapi segar yang dikoleksi dari peternakan sapi perah perorangan. Sebanyak 104 sampel susu sapi segar dikoleksi dari Pangalengan-Bandung dan Sukabumi (propinsi Jawa Barat), serta Tanggamus (propinsi Lampung) pada bulan April dan September 2012. Semua sampel dianalisis secara kromatografi cair kinerja tinggi (KCKT) dan dideteksi dengan fluoresen detektor setelah dilakukan ekstraksi dengan pelarut organik. Kontaminasi AFM1 ditemukan pada 1,96\% (1/51) dari sampel yang dikoleksi pada bulan April 2012 pada konsentrasi 1,20 ng/L dan 39,63\% (21/53) dari sampel yang dikoleksi pada bulan September 2012 pada konsentrasi 1,0 - 34,1 ng/L. Sampel positif diperoleh dari sampel yang berasal dari Pangalengan dan Sukabumi, tetapi tidak ditemukan untuk sampel yang berasal dari Tanggamus pada pengumpulan bulan April maupun September 2012. Dari keseluruhan sampel positif AFM1 yang ditemukan, tidak ada sampel yang mengandung AFM1 melebihi batas maksimum (BM) yang diregulasikan di Indonesia (500 ng/L or $0.5 \mu \mathrm{g} / \mathrm{L}$ ). Kontaminasi AFB1 pada kisaran 0,38 hingga 6,64 $\mu \mathrm{g} / \mathrm{kg}$ ditemukan pada sampel pakan dari lokasi dan waktu pengumpulan yang sama. Temuan kontaminasi AFM1 pada susu segar yang dianalisis pada penelitian ini tidak membahayakan kesehatan manusia. Namun, pengawasan secara regular terhadap kontaminasi AFM1 pada susu dan AFB1 pada pakan sapi perah tetap diperlukan untuk menjamin kesehatan masyarakat.
\end{abstract}

Kata Kunci: Residu, Aflatoksin M1, Susu, Peternakan Rakyat, KCKT

\section{ABSTRACT}

Widiastuti R, Anastasia Y. 2018. Aflatoxin M1 residue in fresh dairy milk from small individual farms in Indonesia. JITV 23(3): 143-149. DOI: http://dx.doi.org/10.14334/jitv.v23i3.1789

This present study was aimed to investigate the presence of aflatoxin M1 (AFM1) residue in fresh dairy milk collected from small dairyl farms. A total of 104 samples of fresh cow's milk were collected in Pengalengan-Bandung and Sukabumi (West Java province), and Tanggamus (Lampung province) in April and September 2012. All samples were analyzed by a high performance liquid chromatography and detected with fluorescence detector after extraction with organic solvents. Contamination of AFM1 was found on 1.96\% (1/51) from the samples collected in April 2012 at concentration of $1.20 \mathrm{ng} / \mathrm{L}$ and $39.63 \%$ (21/53) from the samples collected in September 2012 at concentration of $1.20 \mathrm{ng} / \mathrm{L} 1.0-34.1 \mathrm{ng} / \mathrm{L}$. Those positive samples were obtained from Pangalengan and Sukabumi, but none for those samples collected from Tanggamus both on collection time April nor September 2012. In those positive samples for AFM1, there is no sample contained AFM1 above the maximum level (ML) regulated in Indonesia ( $500 \mathrm{ng} / \mathrm{L}$ or $0.5 \mu \mathrm{g} / \mathrm{L}$ ). Low contamination levels of AFB1 in the range of 0.38 to $6.64 \mu \mathrm{g} / \mathrm{kg}$ found in supplemental feed samples from the same sampling time and locations. The findings of AFM1 contamination in raw fresh milk from this study caused no harm to the consumers. However, regular monitoring on the presence of AFM1 in dairy milk and aflatoxin B1 (AFB1) in dairy cattle feed is necessary to ensure the protection of human health.

Key Words: Residue, Aflatoxin M1, Milk, Small Individual Farms, HPLC

\section{INTRODUCTION}

Indonesia as a tropical country has a climate characterised by high humidity and high temperature which favours the growth of fungi in food products, and therefore the potential for the production of mycotoxins. Aflatoxins especially aflatoxin B1 (AFB1) isthe most toxic and carcinogenic mycotoxin. Aflatoxin B1 is metabolised into aflatoxin $\mathrm{M}_{1}$ (AFM1) and excreted in milk (Agus et al. 2010)
There is a relation between food contaminated with aflatoxins and that fed to animals, and aflatoxin M1 in milk (Kang'Ethe \& Lang 2009). About 0.3 to $6.2 \%$ of AFB1 in animal feeds is converted to AFM1, and it can be found in milk 12 hours after first ingestion and decreases to an undectable level 72 hours after las ingestionof AFB1 (Creppy 2002). Sumantri et al. (2012) revealed the conversion of AFB1 to AFM1 in Indonesia cattle was low $(0.1 \%)$ compared than that in sub-tropical countries (around 1 to 3\%). In addition, Agus et al. (2013) suggested that low conversion value 
(0.32 to $0.82 \%)$ of Indonesian Friesian Holstein cattle is related to its low milk yield level. Mahmoudi \& Norian (2015) suggested that the contamination levels of AFM1 in raw milk are dependent on the amount of AFB1 contained in feed animal (especially corn silage) to dairy cattle.

Aflatoxin M1 occurrence in dairy products may be considered as a possible hazard for public health and also can its residue be found in human breast milk (Kilic Altun et al. 2017). Its occurrence had been reported and reviewed from many countries. In 2012 a Working Group of the International Agency for Research on Cancer (IARC) finally concluded that there was sufficient evidence in humans for the carcinogenicity of aflatoxins (including aflatoxin M1) and classified as carcinogenic to humans (Group 1) (Ostry et al. 2017).

AFM1 was reported stable on pasteurization process or other milk processing such cheese making and storage (Fernandes et al. 2012; Sanli et al. 2012). Because of health concerns and regulatory limits, there is a Codex maximum level (ML) for a contaminant (including mycotoxins of AFM1) in a food or feed commodity, that is the maximum concentration of contaminant be legally permitted in that commodity as recommended by the Codex Alimentarius Commission (Codex Alimentarius 2015). The ML for AFM1 in milk is vary ranging from 0.02 to $0.05 \mathrm{ng} / \mathrm{mL}$ depending on the country. The ML of AFM1 in Indonesia is 0.5 $\mathrm{ng} / \mathrm{mL}$ (BSN 2009) which is similar to the MLs adopted in other Asian countries such as China, South Korea, Japan, Malaysia, the Phillipines, Singapore, Taiwan and Vietnam (Anukul et al. 2013). Additionally, the Indonesian regulation also governing the maximum limit of AFM1 in milk and milk based products (including pasteurized milk) at $0.5 \mathrm{ng} / \mathrm{mL}$ as stated by the Head of Indonesia National Agency of Drug and Food Control No. HK.00.06.1.52.4011 (BPOM 2009).

Fresh raw milk in Indonesia producedby cows that managed by individual smallholder farmers (owning about 3 to 10 cows). Milk arecollected to the local dairy center known as the dairy farmer cooperative (koperasi susu, Ind) before sent to the dairy processing companies. It is important to determine AFM1 levels in milk and dairy products in order to protect consumers of various age groups from its potential hazards. It is a necessitate for monitoring of AFM1 in fresh dairy milk before it processed further. Unfortunately, only few studies on AFM1 contamination in fresh dairy milk had been reported from Indonesia (Widiastuti et al. 2006; Nuryono et al. 2009). Therefore, the present study aimed to examine the the presence of AFM1 on raw dairy milk collected from small individual dairy farms in three different locations i.e Pangalengan-Bandung and Sukabumi (West Java), and Tanggamus (Lampung) in April 2012 and September 2012. This research was necessary to fulfill lack of supply data for the presence of AFM1 residue in fresh milk in Indonesia.

Mahmoudi \& Norian (2015) suggested that the contamination levels of AFM1 in raw milk are dependent on the amount of AFB1 contained in feed animal (especially corn silage) to dairy cattle. Prandini et al. (2009) reported the most important risk factor for the AFM1 level in milk was the AFB1 concentration in supplemental feed component such as maize, groundnuts. Therefore the supplemental feeds such as cocoa pods, concentrate feed and rice hulls were also analysed for AFB1 to study its correlation with the occurrence of AFM1 in milk.

\section{MATERIALS AND METHODS}

\section{Sample collection}

A total of 104 fresh raw cow milk samples were collected in two different seasons, i.e at the end if wet season (April) 2012 and at the end of dry season (September) 2012. Those samples composed of 15 samples from Pangalengan (Bandung), 17 samples from Sukabumi and 19 samples from Tanggamus (Lampung) that collected in April 2012, and 14 samples from Pangalengan (Bandung), 19 samples from Sukabumi and 20 samples from Tanggamus (Lampung) that collected in September 2012. All samples were collected from small individual farms and carried out in the morning or evening milking time before were sent to dairy milk cooperative in every locations. Each sample of $200 \mathrm{~mL}$ in volume brought in a $250 \mathrm{~mL}$ plastic bottle, and transported to the laboratory in an ice box at temperatures about $4^{\circ} \mathrm{C}$ and then stored at $-20^{\circ} \mathrm{C}$ until analysis of AFM1 residue.

A variety of supplemental feed samples for AFB1 analysis were also collected at the same time and same location of milk sampling. Those samples composed of 6 coconut cakes and 14 rice hulls, 3 cocoa pods and 2 cencentrate feeds were collected from Pangalengan (Bandung) and Sukabumi in April 2012. Whereas 17 rice hulls, 3 cocoa pods and 5 coconut cakes were collected from Bandung and Sukabumi in September 2012. None of supplemental feeds were obtained from Tanggamus (Lampung) in both sampling collection times. Each sample of 500 gr were brought in a plactic bag, and transported to the laboratory and then stored at $-20^{\circ} \mathrm{C}$ until analysis.

\section{Sample extraction for preparation of AFM1 analysis in milk}

All milk samples were thawed gradually at $4^{\circ} \mathrm{C}$ and then vigorously mixed. The extraction method of AFM1 was modified from the Association of Analytical Chemists (AOAC) (Widiastuti et al. 2006). Ten $\mathrm{mL}$ of 
thawed milk sample was transferred into a $125 \mathrm{~mL}$ glass beaker containing $30 \mathrm{~mL}$ hot water $\left(75^{\circ} \mathrm{C}\right)$ and shaked for 15 minutes. The sample was then filtered through a Whatman filter paper No. 41 and then slowly passed through to an SPE $\mathrm{C}_{18}$ (conditioned previously with $5 \mathrm{~mL}$ methanol and $5 \mathrm{~mL}$ deionized water) placed in a vacuum manifold. The cartridge was rinsed with a mixture of deionized water and acetonitrile (95:5, v/v) and the SPE $\mathrm{C}_{18}$ cartridge was removed and the inside of both stems were dried with tissue paper and was primed by adding $150 \mu \mathrm{L}$ acetonitrile to the inlet and let solvent soaked into packing for 30s. The SPE C18 cartridge was attached tandemly with an SPE silica column (activated previously with $5 \mathrm{ml}$ ether) below the SPE $\mathrm{C}_{18}$ cartridge. Both cartridges were washed with 5 $\mathrm{mL}$ ether and the SPE $\mathrm{C}_{18}$ cartridge was released. The SPE silica column was rinsed with $2 \mathrm{ml}$ ether. Finally, the AFM1 was eluted with $7 \mathrm{ml}$ mixture of dichloromethane and ethanol $(95: 5, \mathrm{v} / \mathrm{v})$ and the eluate evaporated to drynessand stored at $-20^{\circ} \mathrm{C}$ in a freezer until further analysis.

\section{Sample extraction for preparation of AFB1 analysis in feeds}

All feed samples were also prepared for AFB1 analysis using the modified method (Widiastuti et al. 2008). Fifty gram sample was added with $200 \mathrm{~mL}$ mixture of methanol-water $(85: 15, \mathrm{v} / \mathrm{v})$ and shaken for about 20 minutes. Forty $\mathrm{mL}$ of filtrate was extracted using $40 \mathrm{~mL}$ of $10 \%$ sodium chloride solution, $25 \mathrm{~mL}$ hexane and shake gently for 1 minute, and let the solution separated into 2 layers. The hexane layer (upper layer) was discarded and the filtrate (lower layer) was then extracted two timeswith $25 \mathrm{ml}$ chloroform. The chloroform layer was passed through anhydrous sodium sulphate that placed upon a Whatman filter paper No. 41. The filtrate was evaporated and dissolved with $3 \mathrm{ml}$ dichloromethane and then eventually applied to an SPE silica cartridge that previously had been activated with $3 \mathrm{ml}$ hexane and $3 \mathrm{ml}$ dichloromethane. After applying the sample, the cartridge was washed with $1 \mathrm{ml}$ dichloromethane, $3 \mathrm{ml}$ hexane, $3 \mathrm{ml}$ anhydrate ether and $3 \mathrm{ml}$ dichloromethane. The residue was eluted with $10 \mathrm{ml}$ a mixture of chloroform and acetone $(9: 1, \mathrm{v} / \mathrm{v})$. The eluate was evaporated to dryness and also stored at $-20^{\circ} \mathrm{C}$ in a freezer until further analysis.

\section{Chromatographic condition for detection of AFM1 and AFB1}

All samples were derivatized before injected to the HPLC by adding $200 \mu \mathrm{L}$ hexane and $50 \mu \mathrm{L}$ trifluoroacetic acid (TFA) and evaporated to dryness on heating block at $100^{\circ} \mathrm{C}$. A mobile phase was added into the derivatized sample and filtered through a $0.22 \mu \mathrm{m}$ (pore size) and 13mm (diameter) PVDF filter (Waters Corp., USA).

Chromatographic condition for identification AFM1 and AFB1 was performedby using a column of $\mathrm{C}_{18} \mathrm{X}$ Terra $\mathrm{RP}_{18}(200 \mathrm{~mm}$ x $4.6 \mathrm{~mm}, 5 \mu \mathrm{m})$ (Waters Corp. USA) coupled with a guard column. The mobile phase for detecting AFM1 was a mixture of ultrapure water, acetonitrile and isopropanol (80:8:12, v/v/v), whereas for detecting AFB1 was a mixture of methanol, acetic acid and ultrapure water (15:20:65, v/v/v). All mobile phases were filtered through a $0.45 \mu \mathrm{m}$ filter membrane, degassed and run isocratically at a flow rate of $1 \mathrm{~mL} / \mathrm{min}$. Twenty $\mathrm{mL}$ of the samples were injected onto the HPLC and detected with a Hitachi fluorescene detector model L 7485 (Hitachi Corp., Japan) which set at $425 \mathrm{~nm}$ emission and $365 \mathrm{~nm}$ excitation).

\section{Chromatographic calculation}

The extraction methods (AFM1 in milk and AFB1 in feed) were accredited according to ISO/IEC 17025. The quality of results is tested in each assay using a negative blank sample. The milk sample spiked with a known level of AFM1 $(50 \mathrm{ng} / \mathrm{L})$ in milk and AFB1 $(40 \mathrm{ng} / \mathrm{kg})$ in feed sample. Interpretation of positive samples were taken based on the value given by the chromatograms that higher than the quantitation limit obtained on the methods. The quantification limit is the lowest amount of analyte in a sample which can be quantitatively determined with suitable precision and accuracy by using the developed HPLC method (Shrivastava \& Gupta, 2011). The quantitation limits were $1.0 \mathrm{ng} / \mathrm{L}$ for AFM1 in milk and $1 \mu \mathrm{g} / \mathrm{kg}$ for AFB1 in feed. A calculation result above the quantitation limit gives a meaning as positive sample, whereas lower than the quantitation limit gives a meaning as trace or not detected (ND).

\section{RESULTS AND DISCUSSION}

\section{Contamination of AFM1 in raw milk samples}

The appearance of AFM1 in milk is within 15 minutes to an hour after the cows consuming AFB1 and decrease to below the limit of detection within $72 \mathrm{hrs}$ and returns to baseline levels within two to three days after AFB1 removed from the diet (van Egmond 1989). Agus et al. (2010) suggested that AFM1 rapidly appeared in milk in the range of 0.08 to $0.20 \%$ of the AFB1 consumed by the from Indonesian Frisian Holsteins (FH) and still detected until 5 days after AFB1 was removed from the diet.

Analysis results for the occurrence of AFM1 contamination in dairy milk from 3 different locations (Pangalengan-Bandung, Sukabumi, and Tanggamus) 
collected in April 2012 and September 2012 presented in Table 1 and 2. Contamination of AFM1 found in $1.96 \%(1 / 51)$ of the samples collected in April 2012 at a concentration of $1.20 \mathrm{ng} / \mathrm{L}$ and $39.63 \%$ (21/53) of the samples collected in September 2012 at a concentration level of 1.0 - $34.1 \mathrm{ng} / \mathrm{L}$ for samples collected from Pangalengan and Sukabumi, but not found in samples from Tanggamus neither collected in April nor September 2012. The highest concentration of AFM1 at $34.1 \mathrm{ng} / \mathrm{L}$ was found in one sample from Sukabumi collected in September 2012. Totally, the incidence of AFM1 contamination is $21.15 \%$ (22 out of 104 samples) with the concentration range of 1 to $34.1 \mathrm{ng} / \mathrm{L}$. None of those samples had AFM1 greater than the maximum level (ML) regulated in Indonesia (500 ng/L or $0.5 \mu \mathrm{g} / \mathrm{L})$.

Those data resulted in this study shows a better comparison to the previous research conducted from the same location in Pangalengan-Bandung in 2003, which was reported that contamination of AFM1 occurred in $85 \%$ among 20 samples in the level range of 2 to 1200 ng/L (Widiastuti et al. 2006). Fillaeli (2007) observed $95 \%$ of milk samples from Yogyakarta were contaminated with AFM1 at concentration level of 33 to 113 ng/L, Nuryono et al. (2009) reported 70\% of the samples observed contaminated with AFM1 at concentration level $\leq 10 \mathrm{ng} / \mathrm{L}$ and Nurhayati (2014) found 54 out of 57 pasteurised milk were consisted of AFM1 at concentration level of 20.77 to $458.87 \mathrm{ng} / \mathrm{L}$. Aflatoxin M1 also was analysed on 20 powdered milk collected from Serang, Bandung, Semarang and Surabaya, and had been reported in the range from undetectable to $0.549 \mu \mathrm{g} / \mathrm{kg}$ and the highest data (55\%) was distributed in concentration range of $>0.05 \mu \mathrm{g} / \mathrm{kg}$ to $0.2 \mu \mathrm{g} / \mathrm{kg}$ (Wijaya et al. 2018).

Our results were better compared to the study conducted by Nadira et al. (2017) in Malaysia who revealed 19 out of 53 samples (35.8\%) were positive with AFM1 ranging from 3.5 to $100.5 \mathrm{ng} / \mathrm{L}$ for detection with ELISA method or the study conducted by Ruangwises \& Ruangwises (2010) in 240 milk samples collected from central region of Thailand which showed the average concentration in winter was $89 \pm 34 \mathrm{ng} / \mathrm{L}$, rainy season was $71 \pm 28 \mathrm{ng} / \mathrm{L}$ and summer was $50 \pm 21 \mathrm{ng} / \mathrm{L}$, and also the study conducted by Goncalves et al. (2017) who found that $40.4 \%$ of samples from small dairy farms in Brazil were above the maximum limit allowed by the Brazilian regulation $(0.5 \mu \mathrm{g} / \mathrm{L})$. In the other hand, our results showed a higher incidence compared to the results in Malaysia (4\% of the analyzed 102 samples) at contamination levels below of $0.5 \mathrm{ng} / \mathrm{kg}$ ) (Shuib et al. 2017).

\section{AFB1 contamination in supplemental feeds}

The levels of AFM1 in milk are influenced by both feeding practices and the types of feedstuffs. The feed supplied to dairy herds in those collection sample regions was predominantly fresh grasses and sometimes mixtured with concentrate or rice hull. Table 3 and 4 present the occurrence of AFB1 in supplemental feeds (coconut cake, rice hull, cocoa pods, concentrate feed) from every locations of milk sampling conducted.

Table 1. The occurrence of AFM1 in raw fresh milk collected in April 2012

\begin{tabular}{lccc}
\hline \hline \multirow{2}{*}{ Sampling locations } & Sample size $(\mathrm{N})$ & \multicolumn{2}{c}{ AFM1 contamination } \\
\cline { 3 - 4 } & & Incidence, $\mathrm{n}(\%)$ & Concentration (ng/L) \\
\hline Pangalengan & 15 & $1(6.66 \%)$ & 1.20 \\
Sukabumi & 17 & none & - \\
Tanggamus & 19 & none & - \\
Total & 51 & $1(1.96 \%)$ & 1.20 \\
\hline
\end{tabular}

Table 2. The occurrence of AFM1 in raw fresh milk collected in September 2012

\begin{tabular}{lccc}
\hline \hline \multirow{2}{*}{ Sampling locations } & Sample size (N) & \multicolumn{2}{c}{ AFM1 contamination } \\
\cline { 3 - 4 } & 14 & Incidence, n (\%) & Concentration (ng/L) \\
\hline Pangalengan & 19 & $7(50.0 \%)$ & $5.3-34.1$ \\
Sukabumi & 20 & $14(77.8 \%)$ & $1.0-33.2$ \\
Tanggamus & 53 & none & - \\
Total & $21(39.63 \%)$ & $1.0-34.1$ \\
\hline
\end{tabular}


The contamination levels of AFB1 in all types of supplemental feed samples were very low (0.38 to 6.64 $\mu \mathrm{g} / \mathrm{kg})$. The highest incidence (100\%) of the presence of AFB1 was found in coconut cake samples collected from Pangalengan in sampling time April 2012 in the average concentration of $4.05 \mu \mathrm{g} / \mathrm{kg}$

The results on the presence of AFB1 in supplemental feed as presented in Table 3 and 4 are in give strong correlation with low incidence and low contamination levels of AFM1 in milk presented in Table 1 and 2 (ranging 1.0 to $34.1 \mathrm{ng} / \mathrm{L}$ ). The most probably reason of low incidence on the presence of AFM1 in April 2012 sampling time might be due to the types of feed given to those animals were fresh grass which were not suitable for the growth of $A$. flavus and/or A. parasiticus. The results of this study in agreement to the finding of Picinin et al. (2013) in Brazil who reported that rainy season caused less of no AFM1 contamination due to widely available of grass and cattle consumed less concentrate feed.

In contrast, AFM1 presents in $39.63 \%$ of samples collected in September 2012 (the end of dry season) indicates that during that time the availability of fresh grass is very limited so that farmers use supplemental feed to fulfill the nutritional needs of cows which in turn lead to the presence of AFM1 in the milk produced, and in agreement with the investigation done by Bilandzic et al. (2017) in Croatia who found that extremely hot temperature during summer and long period of drought without rain may stimulate the development of toxigenic mould to synthezise AFB1 to AFM1 and increased the incidence and the concentration of AFM1. These findings, differ to the investigation conducted in Iran by (Mahmoudi \& Norian 2015) who found that the average contamination levels of AFB1 from summer were lower than from winter.

Low concentration of AFB1 in supplemental feed supports the fact of low concentration of AFM1 in milk samples. Mahmoudi \& Norian (2015) found $82.40 \%$ (178/216) of corn silage, alfalfa hay and concentrate samples from difference dairy farmers were positive for AFB1 in the average AF level of $1.55 \pm 0.89 \mu \mathrm{g} / \mathrm{kg}$ and mostly related to the corn silage, and $36.51 \%$ (65/178) of the samples had AF levels that exceeded $5 \mu \mathrm{g} / \mathrm{kg}$.

Since that the contamination levels of AFM1 in raw milk are dependent on the amount of AFB1 contained in feed, it is important also to consider the maximum limit of AFB1 in feed destined for dairy cattle. The maximum limit of AFB1 in Indonesia according to SNI $3148.1: 2009$ is $200 \mu \mathrm{g} / \mathrm{kg}$ (BSN 2009) is too high compared to the recommendation by Food and Drug Adminstration (FDA) in United States of $20 \mu \mathrm{g} / \mathrm{kg}$ (FAO 2004) by assuming the average of transfer rate of AFB1 to AFM1 is 66:1 (or equal to $300 \mathrm{ng} / \mathrm{L}$ of AFM1).

Table 3. The occurrence of AFB1 in supplemental feeds collected in April 2012

\begin{tabular}{llccc}
\hline \hline \multirow{2}{*}{ Sampling locations } & Sample types & Sample size (N) & \multicolumn{2}{c}{ AFB1 contamination } \\
\cline { 4 - 5 } Pangalengan & Coconut cake & 6 & Incidence, n (\%) & Average concentration $(\mu \mathrm{g} / \mathrm{kg})$ \\
\cline { 3 - 4 } Sukabumi & Rice hull & 8 & $3(100 \%)$ & 4.05 \\
& Rice hull & 8 & $3(37.5 \%)$ & 4.18 \\
& Cocoa pods & 3 & $2(66.6 \%)$ & 0.45 \\
Tanggamus & Concentrate feed & 2 & $1(50.0 \%)$ & 0.38 \\
\hline
\end{tabular}

$\mathrm{NA}=$ not available

Table 4. The occurrence of AFB1 in supplemental feeds collected in September 2012

\begin{tabular}{llccc}
\hline \hline \multirow{2}{*}{ Sampling locations } & Sample types & Sample size (N) & Ancidence, n (\%) & Average concentration $(\mu \mathrm{fg} / \mathrm{kg})$ \\
\cline { 4 - 5 } Bandung & Rice hull & 15 & $6(44.4 \%)$ & 6.64 \\
Sukabumi & Rice hulls & 2 & - & ND \\
& Cocoa pods & 3 & $1(33.3 \%)$ & 0.53 \\
& Coconut cakes & 5 & $1(20.0 \%)$ & 3.41 \\
Tanggamus & NA & - & - & - \\
\hline
\end{tabular}

$\mathrm{NA}=$ not available; $\mathrm{ND}=$ not detected 


\section{CONCLUSION}

Contamination of AFM1 was found on 1.96\% (1/51) from the samples collected in April 2012 at concentration of $1.20 \mathrm{ng} / \mathrm{L}$ and $39.63 \%$ (21/53) from the samples collected in September 2012 at concentration of $1.20 \mathrm{ng} / \mathrm{L} 1.0$ - $34.1 \mathrm{ng} / \mathrm{L}$. Those positive samples were obtained from Pangalengan and Sukabumi, but none for those samples collected from Tanggamus both on collection time April nor September 2012. In those positive samples for AFM1, there is no sample contained AFM1 above the maximum level (ML) regulated in Indonesia $(500 \mathrm{ng} / \mathrm{L}$ or $0.5 \mu \mathrm{g} / \mathrm{L})$. Low contamination levels of AFB1 in the range of 0.38 to $6.64 \mu \mathrm{g} / \mathrm{kg}$ found in supplemental feed samples from the same sampling time and locations.

The findings of AFM1 contamination in raw fresh milk from this study caused no harm to the consumers. However, regular monitoring on the presence of AFM1 in dairy milk and aflatoxin B1 (AFB1) in dairy cattle feed is necessary to ensure the protection of human health.

\section{ACKNOWLEDGMENT}

Authors sincerely thank to the Indonesian Agency for Agricultural Research and Development, Ministry of Agriculture for supporting this study by the Indonesian Research Center for Veterinary Science Research Projects Funding (Project No: 1806.24A). This work was conducted with the help form the staff of Districts Livestock Services in Bandung, Sukabumi, and Tanggamus for their permission and assistance in samples collection and Mr. R. Firmansyah (IRCVS) for his help in analysing the samples. The authors declare no competing financial interest.

\section{REFERENCES}

Agus A, Khuluq I, Sumantri I, Noviandi CT, Nuryono. 2010. Aflatoxin M1 excretion in the milk of tropical dairy cow fed contaminated aflatoxin B1 in the diet. The 5th International Seminar on Tropical Animal Production Community Empowerment and Tropical Animal Industry. Yogyakarta (Indonesia). p. 282-285.

Agus A, Sumantri I, Murti TW, Boehm J. 2013. Survey on the occurence of aflatoxin b1 contamination in dairy ration and its carry over into the milk in Yogyakarta and Central Java Provinces of Indonesia. Paper for Presented in ISM-Mycored International Conference Europe 2013.

Anukul N, Vangnai K, Mahakarnchanakul. 2013. Significance of regulation limits in mycotoxin contamination in Asia and risk management programs at the national level. J Food Drug Analysis. 21:227-241.

Asi MR, Iqbal SZ, Arino A, Hussain A. 2012. Effect of seasonal variations and lactation times on aflatoxin M1 contaminationin milk of different species from Punjab, Pakistan. Food Control. 25:34-38.

[BSN] Badan Standarisasi Nasional. 2009. SNI 7385:2009. Batas maksimum mikotoksin dalam pangan. Jakarta (Indones): Badan Standarisasi Nasional.

[BPOM] Badan Pengawas Obat dan Makanan Republik Indonesia. 2009. Peraturan Kepala Badan Pengawas Obat dan Makanan Republik Indonesia. Nomor HK.00.06.1.52.4011 tentang Penetapan Batas Maksimum Cemaran Mikroba dan Kimia dalam Makanan. Jakarta (Indones): Badan Pengawas Obat dan Makanan Republik Indonesia.

[BSN] Badan Standarisasi Nasional. 2009. SNI. 3148.1:2009. Pakan konsentrat - Bagian I: Sapi Perah. Jakarta (Indones): Badan Standarisasi Nasional.

Bilandžić N, Varenina I, Solomun K, Božica, Božić L, Đurđica, Varga I, Želježić B, Cvetnić L, Benić M, Tanković S, Cvetnić Ž. 2017. Occurrence of aflatoxin M1 in raw cow, goat and sheep milk during spring and autumn in Croatia during 2016. Toxin Reviews. 36:1-7.

Codex Allimentarius. 2015. General standard for contaminants and toxins in food and feed (Codex STAN 193-1995). [accessed August 28th 2018]. www.fao.org/input/download/.../17/CXS_193e_20 15.pdf

Creppy EE. 2002. Update of survey, regulation and toxic effects of mycotoxins in Europe. Toxicol Lett. 127:19-28.

van Egmond HP. 1989. Mycotoxins in dairy products. Aflatoxin M1: Occurrence, Toxicity, Regulation. London (UK): Elsevier Applied Science. p. 11-55.

Fernandes AM, Corrêa B, Rosim RE, Kobashigawa E, Oliveira CAF. 2012. Distribution and stability of aflatoxin M1 during processing and storage of Minas Frescal cheese. Food Control. 24:104-108.

Fillaeli A. 2007. Cemaran alami aflatoksin B1 dalam pakan konsentrat dan aflatoksin M1 dalam susu sapi perah (Thesis). [Yogyakarta (Indones)]: Gadjah Mada University.

[FAO] Food and Agriculture Organization. 2004. Worldwide regulations for mycotoxins in food and feed in 2003. Feed and Nutrition Paper 81. Rome 
(Italy): Food and Agriculture Organization of the United Nations.

Goncalves L, Dalla Rosa A, Gonzales SL, Feltes MC, Baliale-Furlong E, Dors GC. 2017. Incidence of aflatoxin M1 in fresh milk from small farms. Food Sci Technol Campinas. 37:11-15.

Kang'Ethe EK, Lang'AKA. 2009. Aflatoxin B1 and M1 contamination of animal feeds and milk from urban centers in Kenya. Afr Health Sci. 9:218226.

K1lıç Altun S, Gürbüz S, Ayağ E. 2017. Aflatoxin M1 in human breast milk in southeastern Turkey. Mycotoxin Res. 33:103-107.

Mahmoudi R, Norian R. 2015. Aflatoxin B1 and M1 contamination in cow feeds and milk from Iran. Food Agric Immunol. 26:131-137.

Nadira AF, Rosita J, Norhaizan ME, Redzwan SM. 2017. Screening of aflatoxin M1 occurrence in selected milk and dairy products in Terengganu, Malaysia. Food Control. 73:209-214.

Nuryono N, Agus A,Wedhastri S, Maryudani YB, Setyabudi FMCS, Bohm J, Razzazi-Fazeli E. 2009. A limited survey of aflatoxin M1 in milk from Indonesia by ELISA. Food Control. 20:721724

Nurhayati D. 2014. Deteksi aflatoksin M1 pada susu pasteurisasi (Thesis). [Bogor (Indones)]: of Bogor Agricultural University.

Ostry V, Malir F, Toman J, Grosse Y. 2017. Mycotoxins as humans carcinogens-The IARC Monograph classification. Mycotoxin Res. 33:6375 .

Prandini A, Tansini G, Sigolo S, Filippi L, Laporta M, Piva G. 2009. On the occurrence of aflatoxin M1 in milk and dairy products. Food Chem Toxicol. 47:984-91.

Picinin LCA, Cerqueira MMOP, Vargas EA, Lana ÂMOQ, ToaldoI M, Bordignon-Luiz MT. 2013. Influence of climate conditions on aflatoxin M1 contamination in raw milk from Minas Gerais State, Brazil. Food Control. 31:419-424.

Ruangwises N, Ruangwises S, 2010. Aflatoxin M1 contamination in raw milk within the central region of Thailand. Bull Environ Contam Toxicol. 85:195-198.

Şanlı T, Deveci O, Sezgİn E. 2012. Effects of pasteurization and storage on stability of aflatoxin M1 in yogurt. Kafkas Üniversitesi Veteriner Fakültesi Dergisi. 18:987-990.

Shrivastava A, Gupta VB. 2011. Methods for the determination of limit of detection and limit of quantitation of the analytical methods. Chronicles Young Scientists. 2:21-25.

Shuib NS, Makahleh A, Salhimi SM, Saad B. 2017. Natural occurrence of aflatoxin M1 in fresh cow milk an human milk. Food Control. 73:966-970.

Sumantri I, Murti TW, Van der Poel AFB, Boehm J, Agus A. 2012. Carry-over of aflatoxin B1-feed into aflatoxin M1-milk in dairy cows treated with natural sources of aflatoxin and bentonite. J Indones Trop Anim Agric. 37:271-277.

Widiastuti R, Maryam R, Bahri S. 2006. Aflatoxin M1 (AFM1) in fresh dairy milk in Pangalengan and Bogor Districts, West Java. Mathius IW, Sendow I, Nurhayati, Murdiati TB, Thalib A, Beriajaya, Suparyanto A, Prasetyo LH, Darmono, Wina E, editors. Proceeding of Seminar Nasional Teknologi Peternakan dan Veteriner. Bogor (Indones): Pusat Penelitian dan Pengembangan Peternakan. p. 239-243.

Widiastuti R, Indraningsih, Firmansyah R. 2009. Analysis of aflatoxin in corn which purified with SPE silica and detected with HPLC. Sani Y, Martindah E, Nurhayati, Puastuti W, Sartika T, Parede L, Anggraeni A, Natalia L, editors. Proceeding of Seminar Nasional Teknologi Peternakan dan Veteriner. Bogor (Indones): Pusat Penelitian dan Pengembangan Peternakan. p. 705710.

Wijaya HR, Widjajanti NI, Silitonga RF. 2018. Detection of aflatoxin M1 in powdered milk and sweetened condensed milk products in several cities in Java with HPLC-fluorescence method. International Symposium on Food and Agrobiodiversity (ISFA) 2017. IOP Conference. Series: Earth and Environmental Science. 102:012028. 